\title{
Mechanical Confining of Sinonasal Anatomic Variants by Computer Tomography in Togo
}

\author{
Abdoulatif Amadou1*, Mawuena Yao Dansou' ${ }^{2}$, Lantam Sonhaye1, Komlan Amoussou1, \\ Mazamaesso Tchaou' ${ }^{2}$, Bidamin N'timon ${ }^{3}$, Kahabilou Atsa Agbangba ${ }^{1}$, Gani Watara1, \\ Komlavi Adjenou ${ }^{1}$
}

\author{
${ }^{1}$ Department of Radiology, Campus University Hospital of Lomé, Lomé, Togo \\ ${ }^{2}$ Department of Radiology, Sylvanus Olympio University Hospital of Lomé, Lomé, Togo \\ ${ }^{3}$ Department of Radiology, University Hospital of Kara, Kara, Togo \\ Email:*amadoulatif@yahoo.fr
}

How to cite this paper: Amadou, A., Dansou, M.Y., Sonhaye, L., Amoussou, K., Tchaou, M., N’timon, B., Agbangba, K.A., Watara, G. and Adjenou, K. (2017) Mechanical Confining of Sinonasal Anatomic Variants by Computer Tomography in Togo. Open Journal of Radiology, 7, 85-94. https://doi.org/10.4236/ojrad.2017.72010

Received: March 19, 2017

Accepted: June 12, 2017

Published: June 15, 2017

Copyright $\odot 2017$ by authors and Scientific Research Publishing Inc. This work is licensed under the Creative Commons Attribution International License (CC BY 4.0).

http://creativecommons.org/licenses/by/4.0/

c) (i) Open Access

\begin{abstract}
Objective: Determine the frequency of the sinonasal mechanical anatomic variants by CT Scan. Patients and method: Six-month retrospective study concerning sinus CT scans in the registers of Teaching Hospitals' Imaging Services of Lomé and Kara (TOGO). It involves patients without distinction of sex, of over 15 years without anomaly that can lead to a modification of the normal anatomical configuration of the paranasal sinuses' cavities. The analysis has been made by only one radiologist. Results: The frequency of mechanical sinonasal anatomic variants stood at $91.87 \%$. The narrowing of the middle nasal turbinate was the variant mostly observed (55.03\%), dominated by the deviation of the nasal septum whose frequency was $25.48 \%$. The narrowing of the infundibulum represented $10.80 \%$ of population. They were more represented by the Haller cell which displayed a frequency of $3.60 \%$. The variants venturing to narrow the upper nasal turbinate, represented only by extra turbinates, involved $1.02 \%$ of the population. The other variants of mechanical sinonasal anatomic variants represented $25.02 \%$. They were dominated by the maxillary sinus septa (11.2\%). Our study showed a feminine predominance which is statistically important for Haller cells $(p=0.037)$ and the ethmoidbulla hypertrophy $(\mathrm{p}=0.0036)$. Conclusion: The anatomic variants of mechanical sinonasal are very frequent in Togo.
\end{abstract}

\section{Keywords}

CT Scan, Anatomic Variants, Mechanical Confining, Paranasal Sinuses

\section{Introduction}

Sinonasal form at each side a whole anatomical functional system, entirely sepa- 
rated from the opposite side. It constitutes the way-in of the respiratory system and plays a filtering, heating and humidification role of the inhaled air, before its admission in the bronchopulmonary tree. They usually present anatomical variants, of which some can expose to infectious risks. The awareness of these variants of infectious risks whose confining mechanism is the narrowing of the maxilla-nasal infundibulum or the middle turbinate [1] is thus necessary.

Conventional radiology does not permit a detailed study of the nasal cavity and paranasal sinuses, and has now largely been replaced by computerised tomographic (CT) imaging [2] [3]. This gives an applied anatomical view of the region and the anatomical variants that are very often found [2] [3]. Thus, the reading of any CT scan concerning sinonasal must include the identification of these anatomical variants, regardless of the indication.

The frequency of anatomic variants in sinonasal was $67 \%$ in the study of PÉREZ-PIÑAS, and 93\% in the Earwakerstudie's. We did not find the studies about anatomic variants in sinonasal in general, and of the variants of confinement in particular in Sub-Saharan Africa.

We undertook this study to establish the frequency and the map anatomical variants of infectious risk.

\section{Patients and Method}

We conducted a six-month retrospective study from July to December 2015. It concerned sinonasal CT scans in the registers of Teaching Hospitals' Imaging Services of Lomé and Kara (TOGO). The sample size was calculated on the basis of the SWCHARTZ formula: $N=Z^{2} . P .(1-P) / d^{2}(N=$ Sample size; $Z=$ Degree of confidence). At $95 \%$ confidence, $\mathrm{Z}=1.96 ; \mathrm{P}=$ Probability of the expected event (Most frequent variant in the literature: $90 \%$; Therefore $\mathrm{P}=0.9$ and $(1-\mathrm{P})=$ $0.1) ; \mathrm{D}=$ Probability of error. If confidence $=95 \%$, therefore error $=5 \%$ and $d=$ $0.05)$.

We retained CT scans of sinonasal of patients without distinction of sex, of over 15 years. These patients should not have any traumatic, facial tumour injuries or any other injuries leading to a modification of the normal anatomical configuration of the paranasal sinus.

The analysis has been made by only one radiologist.

We had written approval from patients.

For each patient, it has been proceeded systematically on the console a meticulous analysis on axial slices and coronal and sagittal reconstructions.

The size of the ethmoidal cells, notably of the ethmoidal bulla, Agger-nasi, Haller cell, has been researched.

The position of the uncinateprocess and its pneumatization have been studied:

The size, direction of the curvature and the number of middles turbinates have been studied: the concha-bullosa has been retained when the two fine strips are divided by relatively developed aerial shelters. The curvature of the middle turbinate was considered as paradoxical when the concave face of the middle turbinate is against the nasal septum. The existence of the extra turbinates has 
been retained by the presence of more than 6 nasal turbinates.

The maxillary sinus was considered as being divided as it existed one or many divisions in itself.

Any deviation more than $4 \mathrm{~mm}$ of the nasal septum with bone spur has been considered as an anatomical variation.

The collected data have been analyzed and processed with epi info 7. The correlation coefficient of Pearson has been calculated. The difference is considered significant if $\mathrm{p}<0.05$.

\section{Results}

Out of 1083 CT scans analyzed, 995 (91.87\%) presented at least mechanical anatomic variants of sinonasal.

We found out only one variant with 834 persons and two variants with 142 persons and three variants with 19 persons. The total was 1175 mechanical anatomical variants of sinonasal in our study.

Persons presenting narrowing of the middle turbinate (Figure 1) were mostly found with a frequency of $55.03 \%$ in population. They have represented $63.40 \%$ of mechanicals anatomics variants (Table 1). The deviation of the nasal septum was the most found among the narrowing of the middle turbinate. It represented $25.48 \%$ of the population of our study, equaling for $37 \%$ of the narrowing of the middle turbinate, and $22.37 \%$ of the mechanicals anatomics variants of sinonasal (Table 2).

The narrowing of infundibular (Figure 2) affected $10.80 \%$ of the population in our study. They represented $10.47 \%$ of the mechanical anatomicvariants of sinonasal (Table 1). Among the infundibular narrowing, the Haller cell (Figure $2(a)$ ) is mostly found. It affects $3.60 \%$ of the population devoted for our study and represented $30.47 \%$ of infundibular narrowing, and 3.3\% of the mechanicalsanatomics variants of sinonasal (Table 2).

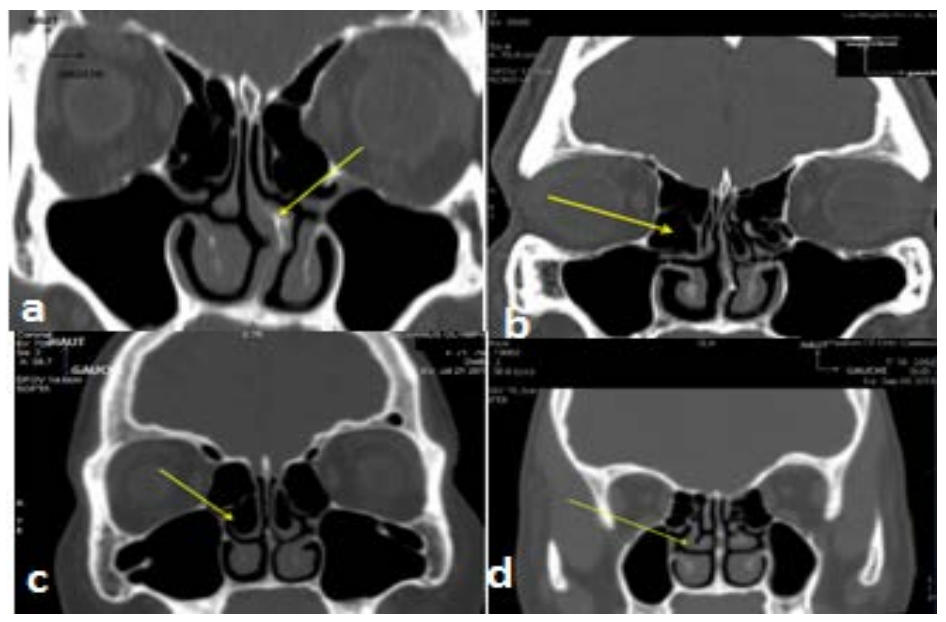

Figure 1. Coronal CT scan: Narrowing of the middle turbinate: (a): Deviation of nasal septal. (b): Hypertrophy of ethmoid bulla. (c): Pneumatization of midlle turbinate (concha bullosa). (d): Paradoxical of middle turbinate. 


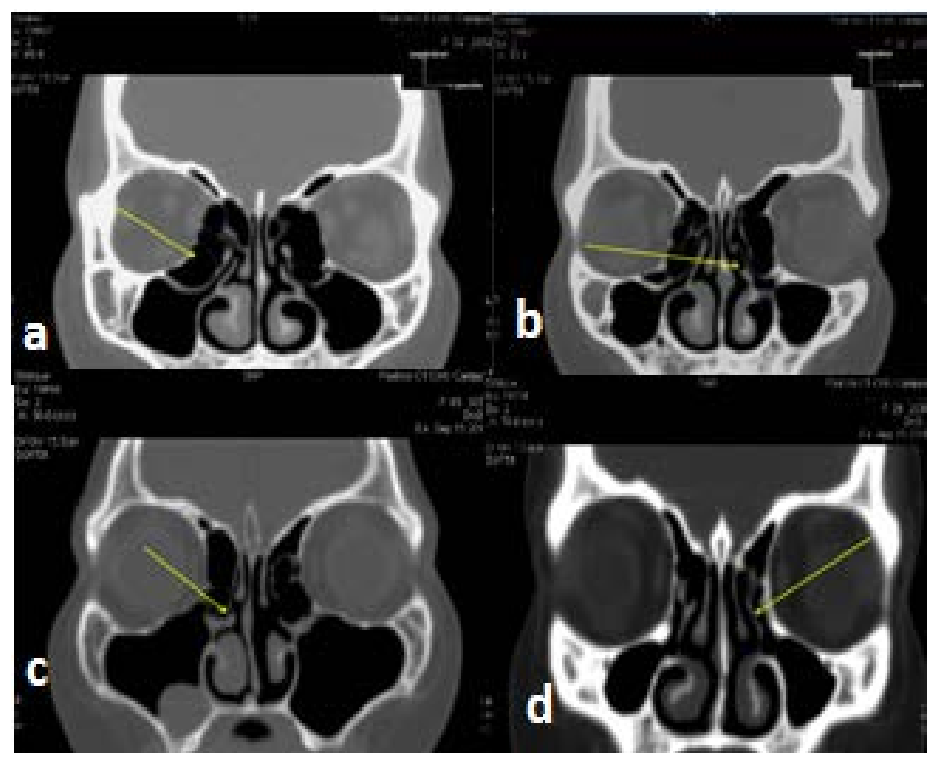

Figure 2. Coronal Ct scan. Narrowing of the infundibular. (a): Haller cell. (b): Pneumatization of uncinateprocessus. (c): Vertically of uncinateprocessus. (d): Horizontally of uncinateprocessus.

Table 1. Distribution of mechanical anatomic variants according to the type of narrowing.

\begin{tabular}{ccccc}
\hline & N1 & N2 & \% VC & $\%$ PE \\
\hline Narrowing of the middle turbinate & 596 & 745 & 63.40 & 55.03 \\
Other mechanical sinonasal variants & 271 & 296 & 25.19 & 25.02 \\
Narrowing of the infundibular & 117 & 123 & 10.47 & 10.80 \\
Narrowing of the superior turbinate & 11 & 11 & 0.94 & 1.02 \\
Total & 995 & 1175 & 100 & 91.87 \\
\hline
\end{tabular}

$\mathrm{N} 1=$ number of persons presenting the mechanical variant. $\mathrm{N} 2=$ Total of variant number. $\% \mathrm{VC}=$ frequency within the mechanical variants: $\mathrm{N} 2$ /total of all mechanical variants $(1175) \% \mathrm{PE}=$ frequency in series: N1/number of scanner analyzed (1083).

The superior turbinate narrowing (Figure 3 ) affected $1.02 \%$ of the population in our study. They represented $0.94 \%$ of the mechanical anatomic variants of sinonasal (Table 1). The extraturbinates (Figure 3 ) were the only narrowing of the superior turbinate (Table 2).

The other mechanical anatomic variants of sinonasal (Figure 4) represented $25.19 \%$ of the mechanical anatomic variants of sinonasal. They represented $25.02 \%$ in the population of our study (Table 1). Among the other variants of confining risk, the maxillary sinus septa (Figure 4(a)) were the mostly found. It affects $11.26 \%$ in the population in our study and represented $41.21 \%$ of the other anatomic variants of sinonasal, and $10.33 \%$ of the whole anatomic variants of sinonasal (Table 2).

We found out a statistically significant feminine predominance for Haller cells $(\mathrm{p}=0.037)$ and ethmoidal bullahypertrophy $(\mathrm{p}=0.0036)($ Table 3$)$. 
Table 2. Distribution of mechanicals anatomics variants.

\begin{tabular}{ccccc}
\hline & Effectif & $\%$ VG & $\%$ PE & $\%$ VC \\
\hline Narrowing of the infundibular & 123 & 11 & 10.80 & 10.47 \\
Haller cell & 39 & 30.47 & 3.60 & 3.3 \\
Pneumatization of uncinate processus & 24 & 18.75 & 2.21 & 2 \\
Horizontally of uncinate processus & 32 & 25 & 2.95 & 2.70 \\
Vertically of uncinate processus & 33 & 25.8 & 3.04 & 2.94 \\
Narrowing of the middle turbinate & $\mathbf{7 4 5}$ & 63 & 63.40 & 55.03 \\
Pneumatization of middle turbinate & 241 & 32.3 & 22.25 & 20.40 \\
Paradoxical of middle turbinate & 61 & 8.17 & 5.63 & 5.16 \\
Hypertrophy of ethmoid bulla & 168 & 22.52 & 15.51 & 14.22 \\
Deviation of nasal septal & 276 & 37 & 25.48 & 22.37 \\
Other mechanical sinonasal variants & 296 & 25 & 2519 & 2502 \\
Hypertrophy of Agger Nasi cell & 93 & 31.41 & 8.58 & 7.87 \\
Hypoplasia of middle turbinate & 71 & 24 & 6.55 & 6.01 \\
Septations of maxillary sinus & 122 & 41.21 & 11.26 & 10.33 \\
Accessory low ostium of the maxillary sinus & 10 & 3.38 & 0.92 & 0.84 \\
Narrowing of the superior turbinate & 11 & 1 & 0.94 & 1.02 \\
Accessories turbinates & 11 & 100 & 1.01 & 0.93 \\
\hline
\end{tabular}

$\% \mathrm{VG}=$ frequency within the group: $\mathrm{N} 2 /$ total variants of the group concerned. $\% \mathrm{VC}=$ frequency within the mechanical variants: $\mathrm{N} 2 /$ total of all mechanical variants. $\% \mathrm{PE}=$ frequency in the study population: $\mathrm{N} 1 /$ number of scanner analyzed.

Table 3. Distribution of mechanicals anatomics variants according to sex.

\begin{tabular}{cccccc}
\hline & \multicolumn{2}{c}{ Women } & \multicolumn{2}{c}{ Men } & KHI \\
\cline { 2 - 6 } & \multicolumn{1}{c}{$\boldsymbol{N}$} & $\%$ & $\boldsymbol{N}$ & $\%$ & \\
\hline Narrowing of the middle turbinate & $\mathbf{2 5 1}$ & $\mathbf{4 2 . 1 1}$ & $\mathbf{3 4 5}$ & $\mathbf{5 7 . 8 8}$ & $\mathbf{0 . 1 1 9 1}$ \\
Deviation of nasal septal & 95 & 34.42 & 181 & 65.37 & 0 \\
Pneumatization of middle turbinate & 100 & 41.49 & 141 & 58.51 & 0.123 \\
Hypertrophy of ethmoid bulla & 91 & 54.17 & 77 & 45.83 & 0.0036 \\
Paradoxical of middle turbinate & 23 & 37.7 & 38 & 62.37 & 0.127 \\
Other mechanical sinonasal variants & $\mathbf{1 2 6}$ & $\mathbf{4 6 . 4 9}$ & $\mathbf{1 4 5}$ & 53.50 & $\mathbf{0 . 0 6 0}$ \\
Septations of the maxillary sinus & 55 & 45.45 & 67 & 54.92 & 0.470 \\
Hypertrophy of Agger Nasi cell & 46 & 49.46 & 47 & 50.54 & 0.169 \\
Hypoplasia of middle turbinate & 37 & 52.11 & 34 & 47.89 & 0.097 \\
Accessory low ostium of the maxillary sinus & 5 & 50 & 5 & 50 & 0.371 \\
Narrowing of the infundibular & 59 & 50.45 & 58 & 49.55 & 0.4456 \\
Haller cell & 23 & 58.97 & 16 & 41.03 & 0.037 \\
Verticallyof uncinate processus & 13 & 39.39 & 20 & 60.61 & 0.263 \\
Horizontally of uncinate processus & 17 & 53.13 & 15 & 46.88 & 0.1710 \\
Pneumatization of uncinate processus & 11 & 45.83 & 13 & 54.17 & 0.4564 \\
Narrowing of the superior turbinate & $\mathbf{5}$ & $\mathbf{4 5 . 5 5}$ & $\mathbf{6}$ & $\mathbf{5 5 . 4 5}$ & $\mathbf{0 . 2 6 3}$ \\
Accessories turbinates & 5 & 45.55 & 6 & 55.45 & 0.263 \\
\hline
\end{tabular}




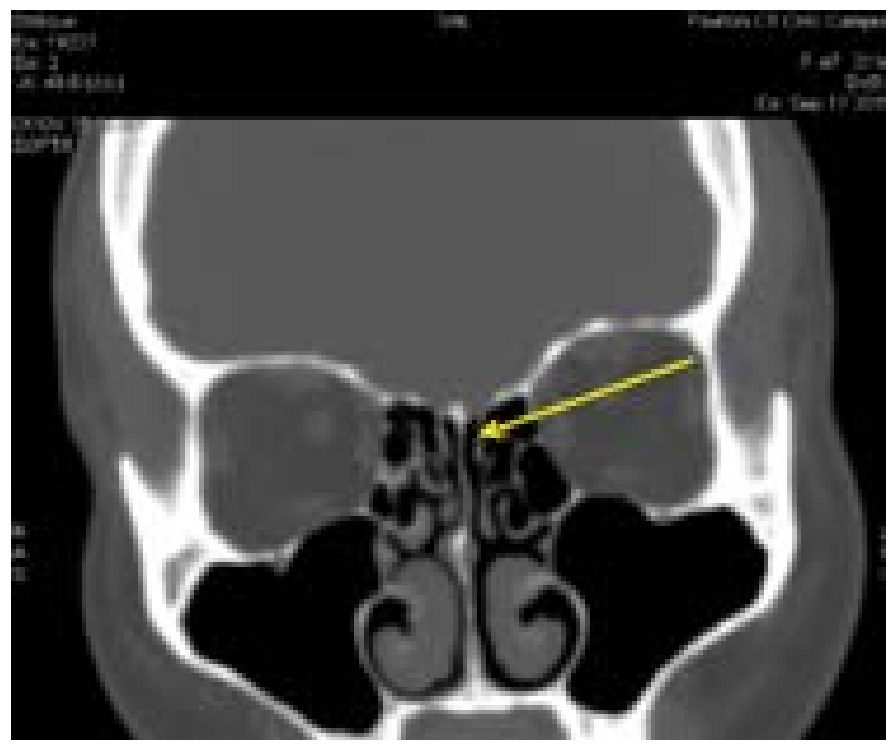

Figure 3. Coronal CT scan. Narrowing of the superior turbinate (Accessories turbinates).

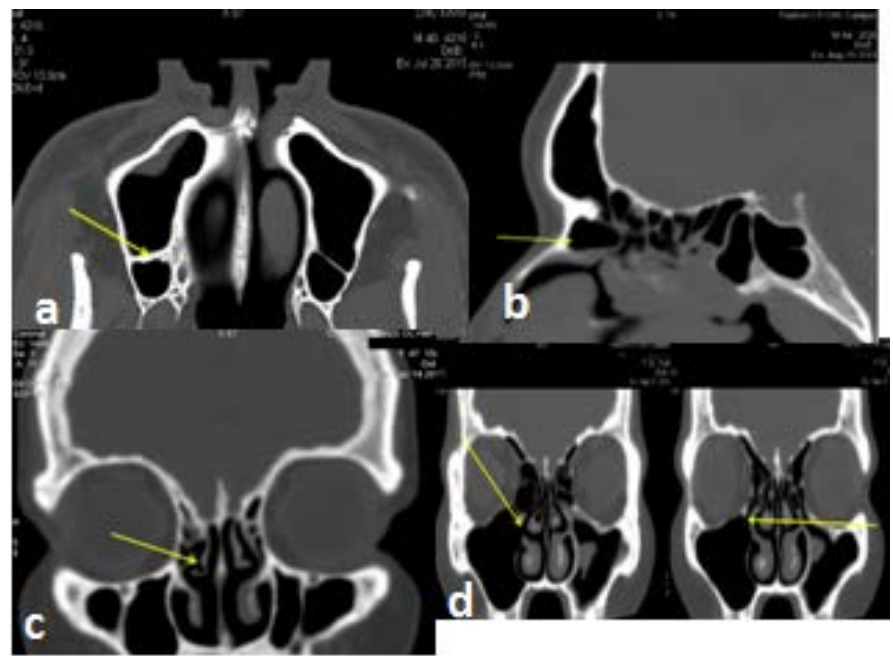

Figure 4. Coronal CT scan: Other mechanical sinonasal variants. (a): Septations of the maxillary sinus. (b): Hypertrophy of AggerNasi cell. (c): Hypoplasia of middle turbinate. (d) Accessory low ostium of the maxillary sinus.

\section{Discussion}

The mechanical anatomic variants of sinonasal are frequent. Their frequency was $91.87 \%$ in our study. It is established that some of these variants represent a rhinosinusitis risk factor, leading to the necessity to raise them out in the sinus CT scans interpretations. Our study found out a predominance of the narrowing variant of the middle turbinate, dominated by the deviation of the nasal septum and the pneumatization of the middle turbinate. In fact, the deviation of the nasal septum occupies the first rank of the mechanical variants and affects $25.48 \%$ of the population of our study, with a statistically significant masculine predominance. Blaugrund et al. [4] found out a frequency of $20 \%$. High frequencies 
were found out by Perez-Pinas et al. [3] (55\%), Kaplanoglu et al. [1] (82\%), Danese et al. [5] (52\%), and Earwaker et al. [2] (44\%). The low frequency of our study can be explained by the choice of our selection criteria on the deviations of the nasal septum. In fact, like some authors [6], we retain a deviation more than $4 \mathrm{~mm}$ of the middle sagittal line with presence with bone spur as variant. Whereas, Kaplanoglu et al. [1] considered any deviation regardless of its scale as a variant. Danese et al. [5] considered the three aspects of the deviation as described by Takanishi et al. [7]. The deviation frequency of the nasal septum in our study is generally ranged between the limit allowed from $9 \%$ to $42 \%$ [8] [9] [10] [11] within the population.

The pneumatization of the middle turbinate (concha bullosa) represented $22.25 \%$ of the population devoted for our study. Our results are comparable to those found out by Perez-Pinas et al. [3] (24.5\%), Basi et al. [12] (21\%) and Jones et al. [13] (20\%). Higher frequencies were found out by Ka-Planoglu et al. [1] (30.4\%), Keast et al. [14] (29\%), Tonai et al. [15] (28\%), and Azila et al. [16] (40.8\%). However Bolger et al. [17] reported a low frequency of $15.7 \%$. The relative frequency variance can be explained by the definition of criteria of a "true" concha bullosa (pneumatization of two portions: vertical (blade) and low (bulla) [3]. A non-significant masculine predominance has been found out in our study in line with Kaplanoglu et al. [1].

The paradoxical middle turbinate represented $5.63 \%$ of the population of our study. This frequency is lower than the one found out by Perez-Pinas et al. [3] which stand at 10\%, and the frequency reported Jones et al. [13] which stands at $11.5 \%$. Some authors [14] [15] [16] found out a frequency varying between $25 \%$ and $33 \%$. It is to be noted that the definition of the paradoxical turbinate is not always easy on a CT scan, as the curvature of the middle turbinate can vary alongside the antero-posterior transit. Our low frequency can be explained by the fact that we took into account only antero-posterior curvatures, while Perez-Pinas et al. [3] considered all the inversion of the middle turbinate.

The ethmoidal bulla hypertrophy represented $15.51 \%$ of the population of our study. This frequency is comparable to that of Danese et al. [5] representing $16 \%$. However, Kaplanoglu et al. [1] reported a very high frequency of $45 \%$. Perez-Pinas et al. [4] registered no case of ethmoidal bubble hypertrophy. Our frequency remains in the required limit (from $8.5 \%$ to 19\%) by most authors [18] [19]. The definition of the bulla hypertrophy can be explained by this variance. We defined an axial diameter higher than $10 \mathrm{~mm}$ to characterize a hypertrophy. Others take into account bulla prolapse with a mass effect on the middle meatus [15].

The infundibular narrowing variants represented $10.47 \%$ of the mechanical variants. They affect $10.8 \%$ of the population of our study. They are essentially represented by the Haller cell which affected $3.60 \%$ of the population. The frequency of the Haller cell stood at $2.7 \%$ in Perew-Pinas et al. study [3], and 2\% in Lloyd et al. study [18]. Higher frequencies were reported by Jones et al. [13] (9\%). The uncinate process is on equal footing or medialized with $2.95 \%$ of the 
population of our study. Our comparable results with that of Perez-Pinas et al. [3] reported a 4.5\% frequency. However, Danese et al. [5] found out a higher frequency of 26\%, as well as Earwaker et al. [2] (19\%). The horizontal uncinate process can come into contact with the middle turbinate. Consequently it can alter the ventilation mechanism of the middle turbinate [19] [20] [21]. In our series, the verticalized uncinate process represented $3.04 \%$ of the population being studied. This proportion is lower than that of Danese et al. [5] (29\%) and Earwaker et al. [2] (32\%). This frequencies inconsistency of deflection injuries of the uncinate process would be due to the deflection definition of the uncinate process. Whereas, we just considered optimal situations of horizontality in contact with the middle turbinate, or verticality narrowing considerably the infundibulum. Authors like Danese et al. [5] used a definition based on angles. They considered any deviation over $30^{\circ}$ compared with the sagittal plan as a medialized or horizontal uncinate process, and any deviation lower than $10^{\circ}$ as lateralized or verticalized process. The pneumatization of the uncinate process represented $2.21 \%$ of the population being studied. Our results, while compared with those of Kaplanoglu et al. [1] found out a frequency of 3.8\%. Perez-Pinas et al. [3] reported no case in their study. However, Danese et al. [5] found out a frequency of $10 \%$. Our frequency is ranged in the required limit in the literature: from $0.4 \%$ to $8.6 \%$ [22] [23] [24].

The other mechanicals confinings variants were dominated by the maxillary sinus partitioning frequency stood at $11.26 \%$. This result is comparable with that of Kaplanoglu et al. [1] which stands at $12.4 \%$. However, Earwaker et al. [2] found out a lower frequency of $2.51 \%$. The partitioning of the maxillary sinus and the accessory ostium represent a $44 \%$ frequency as for Marsot-Dupuch et al. [26]. The frequency of the both variants in our study stood at $12.18 \%$, with a frequency of $0.92 \%$ for the accessory ostium of the maxillary sinus. The hyper-pneumatization of Agger Nasi cell represented 8.5\% of the population being studied. This result is close to that of Bruner et al. [25] which reported a frequency of $10 \%$. Higher frequencies have been found by Ka-Planoglu et al. [1] (63.8\%), Azila et al. [16] (81.2\%), Keast et al. [14] (94\%), Perez-Pinas et al. [3] (100\%) and Tonaï et al. [15] (86.7\%). The fact to consider only a hyper-pneumatization of Agger-Nasi cell which is supposed to have a mass effect on the front-nasal mechanism as anatomical variant can explain the deviations observed in the frequencies. Many authors, unlike us considered the only presence of the Agger-nasi cell as variant [1] [3] [6].

The narrowing of the superior turbinate, represented essentially by the extra turbinated represented $1.01 \%$ of the population being studied. Marsot-Dupuch et al. [26] found out a $6 \%$ frequency.

\section{Conclusion}

The mechanical anatomic variants of sinonasal are very frequent in Togo. They are dominated by narrowing of the middle turbinate, particularly the deviation of the nasal septum and the concha bullosa. 


\section{Conflict of Interests}

The authors declare that there is no conflict of interest regarding the publication of this paper.

\section{References}

[1] Kaplanoglu, H., Kaplanoglu, V, Dilli, A., et al. (2013) An Analysis of the Anatomic Variations of the Paranasal Sinuses and Ethmoid Roof Using Computed Tomography. The Eurasian Journal of Medicine, 45, 115-125. https://doi.org/10.5152/eajm.2013.23

[2] Earwaker, J. (1993) Anatomic Variants in Sinonasal CT. Radiographics, 13, 381415. https://doi.org/10.1148/radiographics.13.2.8460226

[3] Perez-Pinas, I., Sabate, J., Carmona, A., Catalina-Herrera, C.J. and Jimenez-Castellanos, J. (2000) Anatomical Variations in the Human Paranal Sinus Region Studied by CT. Journal of Anatomy, 197, 221-227. https://doi.org/10.1046/j.1469-7580.2000.19720221.x

[4] Blaugrund, S.M. (1989) The Nasal Septum and Concha Bullosa. Otolaryngologic Clinics of North America, 22, 291-306.

[5] Danese, M., Duvoisin, B., Agrifoglio, A., et al. (1997) Influence des variantes anatomiques nasosinusales sur les sinusites récidivantes, persistantes ou chroniques. Journal of Radiology, 78, 651-657.

[6] Ben Amara, F., Toumi, N., Salem, A., et al. (2009) Les variantes anatomiques des sinus de la face: éléments à préciser dans le compte rendu du scanner. Journal of Radiology, 84, 1559. https://doi.org/10.1016/s0221-0363(09)76104-9

[7] Takanishi, R. (1987) The Formation of the Nasal Septum and Étiology of Septal Deformity. Actaotolaryngologica, 29, 303-314.

[8] Calhoun, K.H., Waggenspack, G.A., Simpson, C.B., Hokanson, J.A. and Bailey, B.J. (1991) CT Evaluation of the Paranasal Sinuses in Symptomatic and Asymptomatic Populations. Otolaryngology-Head and Neck Surgery, 104, 480-483. https://doi.org/10.1177/019459989110400409

[9] Gwaltney, J.M., Phillips, C.D., Miller, R.D. and Riker, D.K. (1994) Computed Tomographic Study of the Common Cold. The New England Journal of Medicine, 330, 25-30. https://doi.org/10.1056/NEJM199401063300105

[10] Gray, L.P. (1987) Deviated Nasal Septum: Incidence and Etiology. Annals of Otology, Rhinology \& Laryngology, 50, 3-20.

[11] Min, Y.G., Jung, H.W. and Kim, C.S. (1995) Prevalence Study of Nasal Septal Deformities in Korea: Results of a Nation-Wide Survey. Rhinology, 33, 61-65.

[12] Basic, A., Basic, V., Jukic, T. and Basic, M. (1999) Computed Tomographic Imaging to Determine the Frequency of Anatomical Variations in Pneumatization of the Ethmoid Bone. European Archives of Oto-Rhino-Laryngology, 256, 69-71. https://doi.org/10.1007/s004050050118

[13] Jones, N.S., Strobl, A. and Holland, I. (1997) A Study of the CT Findings in 100 Patients with Rhino Sinusitis and 100 Controls. Clinical Otolaryngology, 22, 47-51. https://doi.org/10.1046/j.1365-2273.1997.00862.x

[14] Keast, A., Yelavich, S., Dawes, P. and Lyons, B. (2008) Anatomical Variations of the Paranasal Sinuses in Polynesian on New Zealand European Computerized Scans. Otolaryngology-Head and Neck Surgery, 139, 216-221. https://doi.org/10.1016/j.otohns.2008.05.014

[15] Tonai, A. and Baba, S. (1996) Anatomic Variations of the Bone in Sinonasal CT. Acta Oto-Laryngologica. Supplementum, 525, 9-13. 
[16] Azila, A., Irfan, M., Rahaizan, Y. and Shamin, A.K. (2011) The Prevalence of Anatomical Variations in Osteomeatal Unit in Patients with Chronic Rhinosinusitis. Medical Journal of Malaysia, 66, 191-194.

[17] Bolger, W.E., Woodruff Jr., W.W., Morehead, J. and Parsons, D.S. (1990) Maxillary Sinus Hypoplasia: Classification and Description of Associated Uncinate Process Hypoplasia. Otolaryngology—Head and Neck Surgery, 103, 759-765. https://doi.org/10.1177/019459989010300516

[18] Lloyd, G.A.S. (1990) CT of the Paranasal Sinuses: Study of a Control Series in Relation to Endoscopic Sinus Surgery. The Journal of Laryngology \& Otology, 104, 477-481. https://doi.org/10.1017/S0022215100112927

[19] Yousem, D.M., Kennedy, D.W. and Rosenberg, S. (1991) Ostiomeatal Complex Risk Factors for Sinusitis: CT Evaluation. JOtolaryngol, 20, 419-424.

[20] Stammberger, H.R. and Wolf, G. (1988) Headaches and Sinus Disease: The Endoscopic Approach. Annals of Otology, Rhinology \& Laryngology, 97, 3-23. https://doi.org/10.1177/00034894880970S501

[21] Ferrie, J.C., Azais, O., Klossek, J.M., Vandermarcq, P., Drouineau, J. and Barret, D. (1992) Exploration tomodensitométrique de l'ethmoïde et du méat moyen. Application à la pathologie infectieuse sinusienne chronique. Journal of Radiology, 73, 93-102.

[22] Gwaltney, J.M., Phillips, C.D., Miller, R.D. and Riker, D.K. (1994) Computed Tomographic Study of the Common Cold. The New England Journal of Medicine, 330, 25-30. https://doi.org/10.1056/NEJM199401063300105

[23] Bolger, W.E., Butzin, C.A. and Parsons, D.S. (1991) Paranasal Sinus Bony Anatomic Variations and Mucosal Abnormalities: CT Analysis for Endoscopic Sinus Surgery. The Laryngoscope, 101, 56-64. https://doi.org/10.1288/00005537-199101000-00010

[24] Arslan, H., Aydınlıglu, A., Bozkurt, M. and Egeli, E. (1999) Anatomic Variations of the Paranasal Sinuses: CT Examination for Endoscopic Sinus Surgery. Auris Nasus Larynx, 26, 39-48. https://doi.org/10.1016/s0385-8146(98)00024-8

[25] Brunner, E., Jacobs, J.B., Shpizner, B.A., Lebowitz, R.A. and Holliday, R.A. (1996) Role of the Aggernasi Cell in Chronic Frontal Sinusitis. Annals of Otology, Rhinology \& Laryngology, 105, 694-700. https://doi.org/10.1177/000348949610500905

[26] Marsot-Dupuch, K. and Genty, E. (2003) Les variantes anatomiques des sinus de la face. Journal of Radiology, 84, 357-367.

\section{Scientific Research Publishing}

\section{Submit or recommend next manuscript to SCIRP and we will provide best service for you:}

Accepting pre-submission inquiries through Email, Facebook, LinkedIn, Twitter, etc. A wide selection of journals (inclusive of 9 subjects, more than 200 journals)

Providing 24-hour high-quality service

User-friendly online submission system

Fair and swift peer-review system

Efficient typesetting and proofreading procedure

Display of the result of downloads and visits, as well as the number of cited articles

Maximum dissemination of your research work

Submit your manuscript at: http://papersubmission.scirp.org/

Or contact ojrad@scirp.org 